\title{
SAYINGS OF JESUS IN THE FOURTH GOSPEL WHICH ARE REMINISCENT OF HIS SAYINGS RECORDED IN THE SYNOPTIC GOSPELS
}

\author{
REV. EDWARD DAY \\ Wichita, Kan.
}

Of late years we have had our attention called very frequently to the fact that the discourses put in the mouth of Jesus by the author of the Fourth Gospel differ widely in character from those recorded in the Synoptic Gospels. Jesus is no longer the untaught, nature-loving Nazarene whose thought finds expression, now in sententious sayings pregnant with wisdom and touched with compassion, anon in parables of rare beauty and rich in suggestion. He is a rabbi whose thought is profound and mystical, rather than clear and logically consecutive. It has been customary to account for this difference by remarking that the Gospel of John reveals adaptation on the part of Jesus to his more cultured hearers in Jerusalem where most of the words here recorded were supposed to have been spoken. This explanation does not satisfy many of our scholars as it once did, especially when it is noted that in the latter part of the third chapter (vss. 26-36) the rough, uncultured man of the desert, John the Baptist, is addressed by his disciples as a rabbi and that he is made to reply in the same profoundly mystical language in which Jesus speaks. Scholars who have come to look upon the Fourth Gospel as a second-century Alexandrian composition feel that it is not necessary to suppose that its discourses were ever delivered by Jesus as reported. Some have gone so far as to speak of them as purely imaginative.

It is not the purpose of the writer of this paper to dwell upon these wide differences in style and character. His intention rather is to dwell upon individual sayings of Jesus found in the Fourth Gospel which appear like reminiscences of sayings of his found in the Synoptic Gospels. It is a singular fact, as will be seen as we go on, that but very few of these sayings may be regarded as directly reminiscent, although the number more remotely reminiscent is considerable. 
Our examination will have to do first with sayings of Jesus which appear to be taken directly from the Synoptic Gospels, or from the same sources from which they were drawn. The need of such a painstaking comparison is the more apparent when it is borne in mind that there seems to be a widespread impression that while in its general tone and character the teaching of Jesus as reported in the Gospel of John differs radically from that found in the first three gospels there are nevertheless very many instances in which the exact words are reproduced.

According to John 4:44 Jesus bore witness to the fact that a prophet hath no honor in his own country. Apparently there is no attempt to give the exact words Jesus is supposed to have uttered. Only the substance of what he said is given. On the other hand, the writer of Matt. 13:57 does purport to give the very words of Jesus: "A prophet is not without honor, save in his own country, and in his own house." Similarly in Mark 6:4, which inserts: "And among his own kindred." This saying is more briefly recorded in Luke 4:24. The context of the saying is the same in all the Synoptic Gospels. The words seem to have been spoken in the synagogue of Nazareth. This can hardly be said of the statement found in John 4:44. Jesus, it is true, is in Galilee, whither he has gone for the time from Jerusalem upon a short tour. Later on, Cana is mentioned; and we are left to infer that the above words were spoken after he passed into Galilee somewhere in the vicinity of Cana, though the writer, it must be confessed, seems to be possessed of little knowledge of the geography of central and northern Palestine. He certainly does not seem to know what Jesus' own country was, further than that it was Galilee. Moreover, the words are meaningless in the context in which they do appear in this gospel, for we are told that when Jesus was come into Galilee the Galileans received him, having seen all the things that he did in Jerusalem at the feast: for they also went unto the feast. Godet admits that this passage has from the beginning been a crux interpretum. His own attempts at reconciliation cannot, however, be regarded with any more favor than those of scholars whose interpretations he renounces. The difference in context we must recognize, whether we do or do not believe that it may be explained satisfactorily; but despite this difference and our 
way of regarding it, we must admit that we have here in John a direct reminiscence of a saying recorded as an early utterance of Jesus in the Synoptic Gospels.

In John 9:39 Jesus is represented as speaking of himself as coming into this world for judgment, that they which see not may see, and that they which see may become blind. This appears to be directly reminiscent of a saying found in the Synoptic Gospels. Luke 8: Io has, "that seeing they may not see, and hearing they may not understand." Mark 4:12a agrees substantially with this; but let us hope that Mark 4:12b, which is a revolting addition to an utterance or saying which is itself perplexing, was not a part of the original remark of the Master. Indeed, for that matter, it is presumable that Matt. I3:I3, where the reason for Jesus' parabolic teaching rather than the purpose of it is given, correctly reports him upon the occasion. It must be admitted that the saying, even in its simplest form, was such as would naturally appeal to the writer of the Fourth Gospel. It certainly seems as though we must have here something in the nature of a quotation, or a reminiscence of a saying, found in the Synoptic Gospels; although it should be noticed that the context in John differs widely from that of the Synoptic Gospels. In the latter it follows the parable of the Sower; while in John it is a part of the remark put in the mouth of Jesus after he had come upon the man whom he had healed and whom the Jews had cast out of the Synagogue. If the one saying is reminiscent of the other and kindred saying, then it was adapted to an entirely different situation.

In John $\mathrm{I} 2: 8$, in the story of the anointing of Jesus, we find the statement: "For the poor ye always have with you; but me ye have not always." Here we have the identical saying that appears in Matt. 26: II, save that in this latter text $\pi a^{\prime} \nu \tau o \tau \epsilon$ stands emphatically at the beginning. The same may be said of Mark 14:7, with this exception, it has the additional clause, "And whenever ye will ye can do them good," a remark that may be regarded as belonging presumably to the original, or an earlier form of the statement. The words of John $12: 7 b$, "Suffer her to keep it against the day of my burying," seem to be reminiscent of Matt. 26:12b, "to prepare me for burial she did it." Nevertheless this thought finds ample expression in Mark I4:8b, "She hath anointed beforehand my body for the burial," 
which again may be even nearer the original saying. The prohibition, "Suffer her," or "Let her alone," reminds us of "Do you let her alone" of Mark I4:6a. The corresponding exclamation in Matt. 26: Io, "Why trouble ye the woman?" is weaker and less likely to have been the original. The entire story as recorded in John appears to have been taken with characteristic changes to suit the purposes of the author, from an earlier narrative, if, indeed, it was not taken directly from the narrative as it is found in Mark. Surely the words which the Fourth Gospel puts in the mouth of Jesus in this narrative are more than reminiscent: they are in the nature of a verbally direct transcript.

John I3:20, "He that receiveth whomsoever I send receiveth me, and he that receiveth me receiveth him that sent me," agrees substantially with Matt. Io:40, "He that receiveth you receiveth me, and he that receiveth me receiveth him that sent me." The dependence of the author of John here, despite the difference in context, upon the passage as it appears in Matthew or of the author of both gospels upon some earlier common source is most manifest. There certainly can be no serious objection to considering the one a quotation from the other because of verbal differences; for we do not expect verbal exactitude in such a case. $\stackrel{a}{\nu} \tau \iota \nu a \pi \epsilon \dot{\epsilon} \mu \omega \omega$ may stand without question for $\dot{v} \mu \hat{a} s$. With Meyer, then, we may speak of "the manifest identity," and may declare that "we are not to explain it in an essentially different sense."

John $17: 2 a$, "Thou hast given him authority over all flesh," may be considered to be directly reminiscent of Matt. 28: I8, "All authority is given unto me in heaven and upon earth;" cf. also Matt. I I :27 and Luke 10:22. As there is some doubt about the postscript of Matthew, many looking upon it as a late addition to the Greek text of the gospel, we may surmise that the authors drew from a common source for the statement. This, however, is very doubtful. Matt. 28:18 may be late enough to show the influence of John $17: 2 a$. Surely the Trinitarian formula of the next verse in Matthew must be later than any part of the Fourth Gospel.

It will be seen from the above study that the number of supposed sayings of Jesus recorded by the author of the Fourth Gospel that appear to be in the nature of direct quotations or reminiscences of 
his sayings recorded in the Synoptic Gospels are very few, and that these may have been drawn in some instances from some sources which were common to all. But the significant fact to be noted is that these utterances do not belong to the more formal discourses of Jesus as reported by the author of the Fourth Gospel. John 4:44 notes that Jesus in going into Galilee testified to a certain fact, using, in so doing, a familiar saying, a homely proverb. Even in the earlier sources the words, it would seem, were connected with the story of Jesus' visit to Nazareth and were not a part of any formal discourse of his. Only one of the Synoptic Gospels (Luke) makes them a part of a somewhat formal address. John 9:39, as it stands, is a saying that does not belong to one of the Johannean discourses. It is a part of the story of a miracle, thoroughly characteristic of the gospel which is the only one in which record of it is found. In Luke it is a part of Jesus' interpretation of the parable of the Sower, and so has a formal place in his teaching. John I2:8 belongs to the story of the anointing, rather than to any discourse of Jesus. The same may

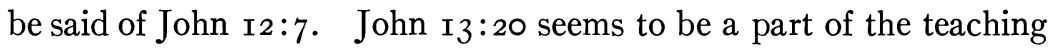
or explanation of Jesus which had to do with his washing his disciples' feet, the narrative of which is found only in the Fourth Gospel. In Matt. IO:40 it appears as a part of a discourse by the Master, but of a discourse of an entirely different character than any which can have grown out of his humble service. John $17: 2$ is not a part of Jesus' teaching but is rather a saying found in the prayer which the author of this gospel ascribes to Jesus on the night of his betrayal. The utterance in Matt. 28:18 is a part of the last words of Jesus, spoken after his resurrection. Not only, then, is it true that the formal teaching of Jesus as reported in thc Fourth Gospel differs radically from his teaching as reported by the Synoptic Gospels, but in its separate sayings also there is a want of agreement, save in fragmentary words of his spoken on special occasions.

It remains, however, to pass on to the examination of a considerable number of passages which are more remotely reminiscent of sayings of Jesus recorded in the Synoptic Gospels. Such sayings are not to be overlooked in any study in which an attempt is made to compare the thought of the Fourth Gospel with that of the first three. John I:42, "Thou art Simon the Son of John: thou shalt be 
called Cephas." This calls to mind parts of Matt. I6: I7-19, "Simon Bar-Jonah," and "thou art Peter." Here in the Fourth Gospel it is only the change of name that is dwelt upon; while in Matthew it is the position of Simon among the apostles and the relation of the new body, the church, to him as its main support. The entire context is different. Here the word is spoken on the occasion of Simon's introduction to Jesus. There it is uttered midway in Jesus' ministry, when the Master and his disciples had retired to the borders of Caesarea Philippi. Whether both incidents are authentic, or only one is, the differences in the utterances and the contradictory nature of the contexts are such as to warrant the statement that the words of Jesus as recorded in the Fourth Gospel are but remotely reminiscent of those found in Matthew.

The words attributed to Jesus in John 2:19, "Destroy this temple and in three days I will raise it up," belong in a class by themselves, for no such utterance is found in any discourse of Jesus recorded in the Synoptic Gospels. Yet he is said to have been quoted by his enemies as having so spoken. In Matt. 26:6I, he is declared by witnesses to have asserted: "I am able to destroy the temple of God and to build it in three days." Then, too, Matt 27:40 tells us that those who railed at Jesus when he was upon the cross intimated that he had made such an assertion. In Mark 14:58 the witnesses are quoted as charging him more explicitly; asserting that he said: "I will destroy this temple that is made with hands, and in three days I will build another made without hands." Less explicit are the words which those who mocked Jesus are said, according to this gospel, to have put in his mouth $(15: 29)$. In none of the synoptic passages is Jesus represented as speaking of a possible destruction of the temple by the Jews themselves. At the most, therefore, we can say that John 2:I9 is remotely suggestive of something which the enemies of Jesus are quoted in the other gospels as putting into his mouth. More might be made of the fact that John 2:I9 appears in the story of the driving of the traders and money-changers from the temple, were it not that the Fourth Gospel is utterly at variance with the others in putting the incident at the beginning of Jesus' ministry upon what seems to have been regarded as one of his earliest visits to the temple. If Jesus ever said anything of the kind he is 
here quoted as saying, he must have done so near the close of his ministry when he was engaged in some such act, let it be presumed, as the driving of unscrupulous and profane men from his Father's house. In that case his words, though distorted, might be brought against him at his trial. It is a singular fact that while the synoptists fail to connect the words with any incident, and one of them speaks of the witness as false (Mark 14:57), the author of the Fourth Gospel does connect the charge, or remark, with such an incident. Nevertheless John 2:19 may be regarded as in some way, though remotely, dependent upon Matt. 26:6I and its allied passages, or some kindred source.

So radically different is the context of John $4: 26$ as compared with the acknowledgment of his messiahship on the part of Jesus, as found in Mark 14:62, and much more as found in Matt. 26:64, that we are hardly warranted in referring to this passage. We can only say that the Fourth Gospel contains an acknowledgment of his messiahship, as the second and first do, and in words that somewhat resemble the words which the Synoptic Gospels put in the mouth of Jesus, strangely as the contexts differ.

John $5: 8$, "Rise, take up thy bed and walk," is found in the narrative of a supposed miracle which is not mentioned in the Synoptic Gospels. A somewhat similar miracle, it is true, is recorded; and in the story of it, curiously enough, we have a similar command put in Jesus' mouth (see Matt. 9:6; cf. Mark 2:II and Luke 5:24).

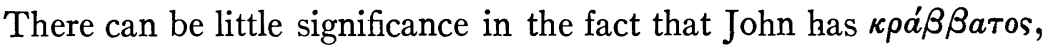
as Mark has, while Luke has $\kappa \lambda \iota \nu i \delta \iota \nu$, for while John has $\kappa a i$ $\pi \epsilon \rho \iota \pi a^{\prime} \epsilon \iota$ the synoptists have an expansion of the same, Matthew and Mark having "and withdraw to thy house," Luke having, "and depart to thy house." Manifestly we do not have a direct quotation, or reminiscence, from any one of the Synoptic Gospels. All that can be said is that as the miracle recorded in John, chap. 5, seems to be remotely reminiscent of that found in the earlier gospels, so also this command seems to be.

John $5: 28,29$ contains the thought of a resurrection from the dead at the word of the Son of Man as judge. The context is altogether different, but the entire passage, taken as a whole, is somewhat suggestive of Matt. 25:3 I ff. According to John 5:29, "they that have 
done good" are to come forth "unto the resurrection of life," while "they that have done evil" are to come forth "unto the resurrection of judgment." According to Matthew those who have failed to provide for the homeless, to clothe the naked, to feed the hungry, to visit the sick and the imprisoned "are to go away into eternal punishment, while those who have ministered unto such, who in other words are righteous in practically beneficent ways, are to enter into eternal life.

John Io: $\mathrm{I}_{4} b, \mathrm{I}_{5} a$, "I know my own, and my own know me, even as the Father knoweth me, and I know the Father" should be compared with Matt. II:27 (see also Luke Io:22), "All things have been delivered unto me of my Father: and no one knoweth the Son, save the Father; neither doth any know the Father, save the Son, and he to whomsoever the Son willeth to reveal (him)." While the connection is altogether different the words of John appear like an unconscious reminiscence of those in the two Synoptic Gospels named above. There is perhaps no saying of Jesus in the other gospels that has more of the flavor of the Alexandrian thought which we come upon as we read the Fourth Gospel than this. It is specially worthy of note that the words as they appear in both Matthew and Luke are strangely mystical and hardly in keeping with the context.

John I $2: 25$, "He that loveth his life loseth it; and he that hateth his life in this world shall keep it unto life eternal," appears like a reminiscence of several passages in the Synoptic Gospels (see Luke 9:24; 17:33; Mark 8:35; Matt. I0:39; 16:25). Though perchance the saying as recorded in John is but an echo, if indeed it be that, of any saying recorded in the other gospels, the context, it should be noted, has not been preserved. In John Jesus is speaking of himself; while in the Synoptic Gospels he has his followers or disciples in mind.

It seems hardly worth while to compare John I2:27a, "Now is my soul troubled" with Matt. 26:38b, "My soul is exceedingly sorrowful, even unto death." Not only is the context different but the utterance in the one case seems hardly such as to have suggested the utterance in the other. It is true that the mere difference in the emphatic word is not conclusive, one way or the other. The $\pi \epsilon \rho i$ $\lambda v \pi \circ$ of the earlier narrative might have suggested the $\pi a \rho a ́ \sigma \sigma \omega$, "I am in inward commotion," "I am agitated," of the later. 
John $12: 36$ has a phrase, "sons of the light," which occurs in another connection in Luke 16:8. This phrase, however, is such as may have occurred to the writer, quite apart from its use in Luke, as a current one (see I Thess. 5:5 and Eph. 5:8).

John I2:44, "He that believeth on me, believeth not on me, but on him that sent me," may be remotely reminiscent of Mark 9:37, or of some kindred saying of the earlier gospel tradition, "Whosoever receiveth me receiveth not me but him that sent me." Yet this is very doubtful.

John I3:13, "Ye call me Master and Lord; and ye say well; for so I am," appears in a widely different context; but it may be regarded as distantly reminiscent of Matt. 23:8b and 1ob, or some similar utterance attributed to Jesus in the original sources.

John $13: 16 b$, "A servant is not greater than his lord" (cf. $15: 20$ ), reminds us of Matt. Io: $24 b$, "Nor a servant above his lord," yet the assertion is of such a general character and appears in the Fourth Gospel in such a context that we are not warranted in saying that it is even remotely reminiscent of it.

The quotation put in the mouth of Jesus in John $\mathrm{I}_{3}: \mathrm{I} 8 b$, "He that eateth my bread lifted up his heel against me," reminds us of Matt. 26:23, which contains a remark of Jesus at his last supper with his disciples, "He that dipped his hand with me in the dish the same shall betray me." The wonder here is that the quotation appears in the later narrative; for we should naturally expect to find it in the earlier, if anywhere in the gospels.

John $14: 26$ and $15: 26$, which contain assurances on the part of Jesus that one whom he calls "the Comforter" will be sent unto them upon his departure, remotely reminds us of Luke 24:49, where allusion is made to "the promise of my Father" for which they are to tarry in Jerusalem.

John 15:14, "Ye are my friends if ye do whatsoever I command you," reminds us somewhat of Matt. 12:50, "For whosoever shall do the will of my Father who is in heaven, the same is my brother, and sister, and mother."

John $16: \mathrm{r} b$, "That ye should not be made to stumble," calls to mind Matt. i : 6b, "Who shall find no occasion of stumbling in me," and even more of Matt. 26:3 I $a$, "All ye shall be made to stumble 
because of me this night." Yet one can hardly be warranted in saying that we have anything more than a remote reminiscence in John $16: 1 b$ of either passage in Matthew. The verb "to cause to stumble" is a very common one in the New Testament.

John $16: 32 b$, "Ye shall be scattered, every man to his own," does not correspond to any word of Jesus found in the Synoptic Gospels; but it does remind us of a quotation of his taken from Zechariah (see Matt. 26:3 I $b$ and Mark $14: 27 b$ ). It would seem that the author of the Fourth Gospel knew that Jesus was reputed to have used this scripture.

John $18: 20 b$, "And in the temple, where all the Jews come together" seems to be remotely reminiscent of Matt $26: 55^{b}$, "I sat daily in the temple teaching." So, too, does John $19: 11 a$, "Thou couldst have no power against me, except it were given thee from above," of Luke $22: 53 b$, "This is your hour, and the power of darkness."

There are only two sayings in the resurrection narratives of the Fourth Gospel which in any way remind us of sayings in the Synoptic Gospels. One is John 20:23, "Whosesoever sins ye forgive, they are forgiven unto them; whosesoever sins ye retain, they are retained." This recalls Matt. $16: 19 b$, "Whatsoever thou shalt bind on earth shall be bound in heaven: and whatsoever thou shalt loose on earth shall be loosed in heaven." 'A фí $\mu \iota$, "to send from, to let go, to remit, as a debt or other obligation," is a common verb in the New Testament used to express the act of forgiving sin. It is not used in Matt. 16: 19b, where we have $\lambda u ́ \omega$, "to loose, to release, to annul or deprive of authority." The connection is different; and in the one case all the disciples are addressed, while in the other only Peter is addressed. It is true, however, that the passage as given in Matthew has been recognized as committing into the hands of Peter not only power not imparted to the other apostles but also authority to absolve from sin. Still it must be admitted that late as is the Fourth Gospel, and above all, doubtful and late as may be the appendix, the passage in Matthew may, as a gloss, be even later. Scholars may be right in regarding it somewhat dubiously. On the whole, then, and especially when the character of the utterances be taken into consideration, it is safer to speak of Matt. $16: 19 b$ as in the nature of a reminiscence of John 20:23, rather than the contrary. 
John $2 \mathrm{I}: 5^{b}$ is the other saying above referred to, "Children, have ye any meat?" This corresponds to Luke $24: 4 \mathrm{I} b$, "Have ye any food to eat?" Although the connection differs somewhat, the question as given in the Lukan narrative may have been in the mind of the author of the appendix of John.

Here again in this part of our study we must be impressed with the fact that the sayings cited do not as a rule belong to the more formal teaching of Jesus recorded in the Fourth Gospel. They have to do largely with supposed incidents of his life and stories of miracles which are somewhat aside from the main currents of the thought as that in full stream, so strangely diverse in character from the teaching recorded in the Synoptic Gospels, flows through this gospel. Several sayings, we have noted, are inconsequential. Such are $12: 36$, a phrase; $13: 16 b ; \mathrm{I}_{3}: 18 b ; \mathrm{I}_{4}: 26$ and $\mathrm{I}_{5}: 26$, a term; I6:I $b$; and I8:20; while John I:42; $2: 19 ; 4: 26 ; 5: 8 ;$ I $2: 27 a$; r6:32 $a$ are considerably to one side of the main currents of Jesus' thought as it is set forth in this gospel. John $5: 27,29 ; 10: 14 b$ and I $5 a ; 12: 25 ; 12: 44$, on the other hand belong to the deeper teaching of Jesus; but there are reasons, as I have suggested, for regarding these passages as not other than remotely reminiscent of sayings of the Master which find a place in the Synoptic Gospels.

Our study can lead to but one conclusion, that the Fourth Gospel cannot be depended upon as an authority in its attempt to set forth the thought of Jesus as a teacher. Not only in the general tenor of of the author's thought, which, as recognized by scholars, is Alexandrian, but in his individual sayings, he is widely separated from the simple, straightforward teacher who stands forth in the pages of the Synoptic Gospels. We are far removed from the early traditions of Jesus' life and work as we tread the dark mazes of the mystical paths of the Fourth Gospel. It cannot be said that justice has yet been meted out to these discourses, many of whose sayings are inconsecutive, illogical, contradictory, and in not a few instances utterly meaningless. This, however, is not what this paper was designed to note. Its task has been far simpler. It has sought only fairly, frankly, and fearlessly to examine such individual sayings as seemed something like reminiscences of sayings found in the other gospels. It was to be expected, if these discourses really belonged to Jesus, if 
he gave utterance to them, that they must, despite all differences of a general character, have many sayings reminiscent of sayings of his found elsewhere. A man cannot, however much his various addresses may differ in style and character, get away from his favorite expressions and stock phrases. But Jesus did so break away, as reported by this gospel. Hence we raise the question whether he is correctly reported? Whether we have not here a report of his words which is largely imaginative? The writer is forced to conclude that in the Fourth Gospel Jesus has been, consciously or unconsciously, misrepresented; and that the discourses attributed to him were largely imaginative. The results of this study are here presented for serious consideration. 